\title{
Matter and Form: Problem 1
}

The opening section of the Shukūk tackles a problem that occurs towards the beginning of Chapter 1 of the Physics and Metaphysics of the Ishärāt. Al-Mas'ū $\mathrm{d}$ attacks Avicenna's theory of matter and body, particularly his proof of prime matter and closely related theory of corporeal form. In what follows, I shall begin by contextualising the problem against the backdrop of Avicenna's hylomorphism and Abū l-Barakāt's criticisms and advocacy of an alternative strand of hylomorphism. We shall then turn to the Ishārāt and Shukūk. ${ }^{1}$

\subsection{Avicenna's Theory of Matter and Corporeity}

According to Avicenna, 'body' (jism) is said of different things. In the sense of 'natural body' (jism țabĩ $\iota$ ), it denotes the substance in which three dimensions (bu'd), perpendicular to one another can be postulated. ${ }^{2} \mathrm{He}$ is, nonetheless, aware that were the dimensions hypothesised to become actual, they would be accidental, rather than essential, features of body; for this reason, he considers this definition a description (rasm) of body, as opposed to a real definition (hadd), which would only consist of essential features of what is defined. ${ }^{3}$ In one place, Avicenna gives the real definition of body as 'the form of continuity (ittișa $\bar{l}$ ), which receives the positing of the three dimensions we have mentioned'4 'Continuity' here is used in the sense of divisibility, which is the absolute sense of the term: a thing is continuous in itself if we can postulate divisions within it, such that any two postulated divisions share a common boundary. ${ }^{5}$

1 See also: Shihadeh, 'Avicenna's Corporeal Form and Proof of Prime Matter'. In the present chapter, Sections 6.1 and 6.2 and part of Section 6.3 draw closely on this article.

2 Avicenna, Țabīìyyāt, I.I.2, 13; Ilāhiyyāt, II.2, 61-63; Hudūd, 22.

3 Avicenna, Ilāhiyyāt, II.2, 63 .

4 Avicenna, Ilāhiyyāt, II.2, 64; cf. Stone, 'Simplicius and Avicenna', 101-102.

5 In addition to this absolute sense, Avicenna gives two further, relative definitions for 'continuity', namely: contiguity, that is, when two bodies share a common boundary, in the sense that their surfaces are in contact; and attachment, that is, when two bodies are attached to one another, either by adhesion or interconnection (Avicenna, Manțiq, II.III.4, 116-117; Ṭabīiyyāt, I.III.2, 269-271; cf. Stone, 'Simplicius and Avicenna', 102).

(C) KONINKLIJKE BRILL NV, LEIDEN, 2016 | DOI:10.1163/9789004302532_008 
Another sense of 'body' is 'mathematical body' (jism ta'limī), which is a non-substantial, but accidental, form that inheres in a corporeal substance. ${ }^{6}$ 'Mathematical body' denotes the accidents of magnitude that are concomitant (lāzim, lāhiq) to natural body in its actual existence in determinate bodies, but do not contribute to the subsistence (qiwām) and realisation (tahaqquq) of corporeity, being accidental rather than essential to it. ${ }^{7}$ For example, finitude is necessarily concomitant to all determinate bodies, because all individual bodies consist of finite parcels of matter. ${ }^{8}$ Associated with finitude are further quantitative accidents, specifically surfaces, determinate dimensions and shapes. ${ }^{9}$ As the quantitative form of any given body is accidental, it is never inherently necessary; yet certain bodies, most notably the celestial spheres, possess fixed magnitudes by virtue of their natures, which are distinct from the corporeity they share with all bodies, and from their specific magnitudes. ${ }^{10}$

Body, in the sense of natural body, is a composite of two primary principles, namely prime matter and corporeal form (șüra jismiyya). These are the two proximate causes to which body owes its subsistence. ${ }^{11}$ The most basic difference between these two principles is that the material cause of body is a passive principle and associated with pure potentiality, whereas the formal cause is an active principle and associated with actuality:

If [the cause of a thing] is included in its constitution and is part of its existence, then either it must be the part where, in terms of its existence alone, ${ }^{12}$ it is not necessary for it to be actual, but only to be in potency, and is termed 'matter'. Or [the cause must be] the part whose existence is its being in actuality, namely form. ${ }^{13}$

Considering its absolute passivity, matter, according to Avicenna, lacks existence of itself and exists only by virtue of being actualised by the form, to which

\footnotetext{
6 Avicenna, Manțiq, II.III.4, 115; Ilāhiyyāt, II.2, 64-65.

7 Avicenna, Ilāhiyyāt, II.2, 62.

8 Avicenna, Ilāhiyyāt, II.2, 62; Manțiq, II.III.4, 113; Ishārāt, 2, 191-195; 2, 227.

9 Avicenna, Ilāhiyyāt, II.2, 62; Ishārāt, 2, 191; 2, 243-244; 2, 227.

10 Avicenna, Ilāhiyyāt, II.2, 64; Najāt, 499; Ishārāt, 2, 174-176.

11 Avicenna, Țabīiyyyāt, I.I.1, 14; Ilāhiyyāt, II.2, 64-65; 257 ff.; Najāt, 190-191.

12 Reading wahdahu, rather than wa-haddihi (Marmura).

13 Avicenna, Ilāhiyyāt, VI.1, 258 (Marmura, 195, with modifications); cf. 257; cf. Belo, Chance and Determinism, $57 \mathrm{ff}$.
} 
it is a mere passive recipient $(q \bar{a} b i l) .{ }^{14}$ It can never be divested of form. ${ }^{15}$ So matter is a principle only accidentally, "because it is first rendered subsistent in act through form, while its essence, considered only in itself, is in potency.' ${ }^{16}$ In the same vein, since matter of itself lacks any actuality, it is not inherently corporeal by predisposition, and hence does not contribute to the actualisation of body qua body.

So body is not corporeal on account of being material. What invests body with corporeity (jismiyya) — that is, three-dimensional continuity—is corporeal form, which is a substantial form combined with prime matter to constitute natural body. Corporeal form is the active principle of body and associated with the actualisation and realisation of body qua body. ${ }^{17}$ Corporeal form is common to all determinate bodies, no individual body having more or less of it than another. ${ }^{18}$

\subsection{Avicenna's Proof of Prime Matter in the Ishärät}

Avicenna proves that body consists of the combination of matter and corporeal form using an argument that starts from body's continuity and susceptibility to discontinuity. We shall only consider here the proof as it appears in Chapter 1 of the Physics and Metaphysics of the Ishārāt, titled 'On the reality of bodies' ( $f \grave{\imath}$ tajawhur al-ajsām). ${ }^{19}$ The proof is preceded by five passages, which make the following points (Ishārāt II.1.1-5):

1. Avicenna, first of all, refutes the belief held by 'some people' that bodies consist of indivisible parts $\left(j u z^{\prime}\right)$, a clear reference to the standard classical kalām atomism taught in Bașran Mu'tazilism and Ash'arism. ${ }^{20}$

\footnotetext{
14 Avicenna, Ilāhiyyāt, VI.1, 258; II.3, 72 ff.

15 Avicenna, Ilāhiyyāt, II.3, 72 ff.; Najāt, 502-506; Ishārāt, 2, $202 \mathrm{ff.}$

16 Avicenna, Ilāhiyyāt, VI.1, 258 (Marmura, 195).

17 Avicenna, Manțiq, II.III.4, 113.

18 Avicenna, Ilāhiyyāt, II.2, 64; 71; Manțiq, II.III.4, 113-114; Țabīìyyāt, I.I.1, 13; Ishārāt, 2, 174; 2, 243-244.

19 On rendering 'tajawhur' as 'reality' (haquiqa), as opposed to 'substantiality', see al-Rāzī, Sharh, 2, 3-4. On the versions that appear in the Shifä' and the Najāt, and on how the Ishärāt argument relates to them, see: Shihadeh, 'Avicenna's Corporeal Form and Proof of Prime Matter'.

20 Avicenna, Ishārāt, 2, 152-157. On this strand of atomism, see Dhanani, Physical Theory.
} 
2. He then refutes the belief held by 'other people' that bodies consist of infinitely divisible parts, which is the theory attributed to the early Mu'tazili al-Naz̧āām (d. 220-230/835-845). ${ }^{21}$

3. From his refutation of atomism in 1 and 2 , he infers that bodies consist of a continuum, and are susceptible to division either actually or in thought. ${ }^{22}$

4. From 3 , it follows that bodies are infinitely divisible, at least in thought. ${ }^{23}$

5. He points out that later in the book, he will prove that motion and time too are continua. ${ }^{24}$

From 3 and 4-that is to say, the continuity and infinite divisibility of bodyAvicenna goes on to infer that body consists of matter and corporeal form. Labelled a 'pointer' (ishāra, by which he means 'proof'), the passage goes as follows (Ishärāt III.1.6):

You have come to know that a body has a continuous, three-dimensional magnitude, and that it is susceptible to discontinuity and fragmentation. You also know that what is continuous in itself is different from the recipient of continuity and discontinuity, whose receptivity is itself attributed by both [i.e. as receptivity to continuity and discontinuity]. Therefore, the potentiality for this reception is different from the existence in actuality of that which is received, and different from its shape and form. This potentiality belongs to [something] other than what is the same as what is continuous in itself, which at the occurrence of discontinuity passes away, and a different [thing] comes to be, and the like of which then comes to be anew at the restoration of continuity. ${ }^{25}$

Although the conclusion is not stated here, Avicenna appears to refer back to this passage a little later in the chapter (Ishärāt II.1.10) as his proof that body consists of the combination of prime matter and corporeal form. ${ }^{26}$ This cross-reference is noted by al-Mas' $\bar{u} d \bar{\imath} .{ }^{27}$

The passage begins with, 'You have come to know', since the starting points of the argument are not self-evident, but have just been demonstrated earlier

\footnotetext{
21 Avicenna, Ishārāt, 2, 158-162.

22 Avicenna, Ishārāt, 2, 163-165.

23 Avicenna, Ishārāt, 2, 166.

24 Avicenna, Ishārāt, 2, 167.

25 Avicenna, Ishārāt, 2, 172-173.

26 Avicenna, Ishārāt, 2, 182-183.

27 Shukūk, 197.
} 
in the chapter: body is continuous, and at the same time divisible. These are two characteristics of body. On the one hand, body is essentially continuous; so it has actual continuity. On the other hand, body is susceptible to both continuity and discontinuity; so it has the potentiality to receive either. Now, these two characteristics of body either belong to one and the same simple substance, or they belong to two different things the combination of which constitutes body. However, the thing that is susceptible to both continuity and discontinuity cannot be the same as continuity itself, because (determinate) continuity passes away at the occurrence of discontinuity, and is replaced with different determinate continuities. Similarly, when two bodies combine into one, their determinate continuities will pass away and be replaced with a new determinate continuity. Therefore, these two characteristics belong to two different things within body: corporeal form, which invests body with actual continuity and is subject to generation and corruption; and matter, to which the potentiality for continuity and discontinuity belongs, and which serves as the substrate for the generation and corruption of continuity.

\subsection{Abū l-Barakāt al-Baghdādī’s Competing Theory of Matter}

In his philosophical summa, the Mu'tabar, Abū l-Barakāt attacks Avicenna's theory that corporeity is a substantial form superadded to prime matter. He opines that Avicenna-whom, in this context, he does not identify by name, but refers to simply as 'an eminent individual' (ba'd al-fudala $\left.{ }^{2}\right)^{28}$ — was misled into developing this theory by a misreading of statements concerning the nature of matter in ancient sources, particularly Aristotle, whom Abū l-Barakāt quotes directly. ${ }^{29}$ When Aristotle asserts that prime matter lacks any inherent quantitative characteristics, he means that matter is deprived of determinate, accidental magnitude, as Abū l-Barakāt explains:

They [i.e. Avicenna] became confused by the assertions of the ancients, who coined this expression [i.e. 'matter' (hayūlä)], when they said that it has neither magnitude, shape, attribute of heaviness or lightness, nor location such as up or down. What [the ancients] meant by this is that, of itself, it is not characterised by any specific magnitude that is bigger or smaller than another, double or half, or any specific attribute such

28 Abū l-Barakāt, Mu'tabar, 3, 201.

29 Abū l-Barakāt, Mútabar, 3, 200-201. 
as lightness or heaviness. [Matter] has none of these [characteristics] by virtue of its essence, or as parts of its essence. ${ }^{30}$

So while Aristotle denies that matter has any inherent determinate characteristics, he can plausibly be read as affirming that matter is essentially corporeal. ${ }^{31}$ Yet Avicenna misinterprets his statements as divesting matter of corporeity altogether, such that if considered separately from form, it would be characterised by neither three-dimensional continuity nor divisibility, and be apprehensible to the mind but imperceptible to the senses. ${ }^{32}$

Against the Avicennan thesis that prime matter does not exist of itself but is only actualised by form, ${ }^{33} \mathrm{Abu}$ l-Barakāt argues that prime matter is in fact body, and accordingly essentially corporeal and characterised by continuous extension (imtidād ittișālī). By analysing (tahlìl) bodies to their basic constituents, both in reality (wujūdī) and in the mind (dhihnī, fì l-nazar), we find that there must be an underlying substrate that all bodily objects share and that persists unchanged as they undergo qualitative alteration. This substrate must be essentially corporeal, as all observed and conceivable alterations that supervene upon bodies affect them qualitatively, but never cause their corporeity to pass away or come to be. ${ }^{34} \mathrm{He}$ writes:

Reflection reveals to us things that we call 'matter' for other things, such as wood for a bed. Wood too has as its matter things that share its substrate with it, but differ from it with respect to form. For when wood is burnt, ash remains and water and air separate. So earth (which is the ash), water and air are the matter of wood, from which it is composed, and to which it decomposes. Therefore, each of water, earth and air is a matter for things that are composed of them, which vary in that they have a higher proportion of some and a lower proportion of others. Finally, these [elements] share corporeity ( jismiyya) among them. Body (jism), hence, is the prime matter for all; yet body itself does not have underlying matter, because we find that it neither is composed of another thing nor becomes decomposed to another thing. ${ }^{35}$

\footnotetext{
30 Abū l-Barakāt, Mu'tabar, 2, 12; cf. 3, 200-201.

31 Abū l-Barakāt, Mu'tabar, 3, 200.

32 Abū l-Barakāt, Mu'tabar, 2, 12.

33 Abū l-Barakāt, Mu'tabar, 2, 16; 2, 123-124.

34 Abū l-Barakāt, Mu'tabar, 2, 10-12; 3, 195-196; 3, 202-203.

35 Abū l-Barakāt, Mu'tabar, 3, 195-196.
} 
Abū l-Barakāt cites the traditional Aristotelian argument from the transmutation of the elements to the presence of an underlying material substrate common to all bodily objects, and remarks that it accords perfectly with his own proof and doctrine of prime matter. Referring to the Aristotelian argument, he writes:

This is none other than the notion [of matter] that we have set out. For when water becomes altered into air, it will lose all the characteristics that characterise water, except corporeity, and it will acquire all the characteristics that characterise air, except corporeity. So what is common and unchanging is [corporeity], and nothing else. ${ }^{36}$

As to Avicenna's theory that prime matter is incorporeal and that body hence consists of the combination of matter and corporeal form, it has no basis in any evidence: 'We have not discerned this so-called 'matter' in body through perception, nor does it result from decomposition, nor are we led to accepting it by $[\ldots]$ a demonstrative argument. ${ }^{37}$

Abū l-Barakāt also confutes Avicenna's argument for the existence of such matter. The thrust of his lengthy response is that the inference starts from change that body undergoes in the accident of magnitude, rather than in corporeity. ${ }^{38}$ He targets the assertion that continuity passes away at the occurrence of discontinuity, for which he considers two possible interpretations. ${ }^{39}$ The first is that the body's continuity passes away completely. Avicenna's argument would be sound if the premise, thus understood, were true. It is, however, false; for division does not cause the continuity of the entire body to pass away, and indeed even if the body is divided infinitely, the outcome of each division will be continuous parts. The second interpretation is that only the continuity between the potential parts of the body divided is lost. If correct, however, this interpretation would render the argument unsound; for the continuity that is lost with division will be a relation, and therefore accidental, rather than substantive. The potential parts, which become actually separate parts, remain unchanged with respect to their corporeity, and undergo neither generation nor corruption by division. As Abū l-Barakāt writes,

\footnotetext{
$3^{6}$ Abū l-Barakāt, Mu'tabar, 3, 201.

37 Abū l-Barakāt, Mu'tabar, 3, 200.

38 Abū l-Barakāt, Mu'tabar, 3, 196-202.

39 Abū l-Barakāt, Mu'tabar, 3, 201-202.
} 
If [a body] is divided, discontinuity will not make its continuity cease to be in the way that the form of air makes the form of water cease to be, so that [the existence of] a thing common to both of them can be established. Rather, it multiplies it. Yet multiplication is not the same as passing away. ${ }^{40}$

Both Avicenna's argument and Abū l-Barakāt's objection became widely influential in the twelfth century. Al-Rāzī reports that the debate had become highly partisan among his contemporaries ('azuma ta'așsubal-nās). ${ }^{41}$ Avicenna's argument from body's susceptibility to discontinuity was the standard philosophical proof (al-burhān al-mashhür) of prime matter. ${ }^{42}$ It is the proof, he writes, on which hylomorphists 'rely and with which they stride around (bi-hāyașūtu$n a) !^{43}$ The same proof, unsurprisingly, is deployed in Bahmanyār's Tahṣill and al-Lawkarī's Bayān al-haqqq, and reported in al-Ghazālī's Maqāṣid al-falāsifa and al-Shahrastānī's Milal.44 Abū l-Barakāt's counterargument, on the other hand, is reproduced by critics of Avicenna, such as al-Shahrastānī. ${ }^{45}$ Ibn Ghaylān alBalkhī, al-Mas'ūdī's colleague, provides the following summary:

Abū l-Barakāt refuted this [argument of Avicenna] in the Mutabar, where he writes: The discontinuity that supervenes on the body does not make its continuity pass away - that is, continuity in the sense of the reality and essence [of body] —it rather multiplies it. ${ }^{46}$ For each of its two parts [which result from division] is essentially a continuous body, no less so than the [original] whole. In fact, what passes away is the continuity that is an accident inhering in it, on account of which it is initially long and then with the passing away of [this continuity] becomes short, or it is initially wide and with this becomes narrow, or it is thick and with this becomes thin. The ${ }^{47}$ extended continuity that is the reality of [body]

\footnotetext{
40 Abū l-Barakāt, Mútabar, 3, 202.

41 Al-Rāzī, Sharh 'Uyūn al-ḥikma, 3, 21.

42 Al-Rāzī, Jawābāt, 12.

43 Al-Rāzī, Mațālib, 6, 201.

44 Bahmanyār, Tahṣill, 312-318; al-Lawkarī, Bayān, 50-54; al-Ghazālī, Maqāṣid, 2, 90-91; alShahrastānī, Milal, 366; cf. idem., Nihāyat al-aqdām, 164.

45 Al-Shahrastānī, Nihāyat al-aqdām, 165. This, he remarks in characteristic fashion, is a philosopher's response to another philosopher (as opposed to a mutakallim's response).

46 Reading yukaththiru-hu rather than bi-kathra.

47 Reading wa-l-ittișāl rather than aw al-ittișāl.
} 
remains unchanged. This is similar to Avicenna's assertion that if a lump of wax is shaped once in the shape of a ball, then in the shape of a cylinder, and so forth, the continuity that is its corporeal form will persist, while its accidents—-namely, length, width and thickness - will change. Therefore, discontinuity and continuity will only supervene in succession upon the continuity that is corporeity; so it does not follow that there must be a matter that receives the form of corporeity. ${ }^{48}$

As al-Rāzī observes in his Jawābāt, Abū l-Barakāt also inspires Section 1 of al-Mas'ū $\mathrm{Ii}^{\prime} \mathrm{S} S h u k u \bar{k}$, to which we should now turn. ${ }^{49}$

\subsection{Al-Mas'ū üi’s Commentary}

Al-Mas'ūdī opens Section 1 of the Shukūk by quoting Avicenna's proof of prime matter (Ishārät II.1.6), and then briefly indicating its unstated conclusion: 'His objective (gharad) in this passage is to demonstrate that body consists of a complex of matter and form; he points this out a little later where he states .... Al-Mas'ūdī then refers to Ishārāt II.1.10, where this conclusion is stated. ${ }^{50}$ No further interpretation of Avicenna's text is provided. The ensuing critical commentary consists of three parts:

1. Al-Mas'ūdī argues that Avicenna's proof falls short of entailing its purported conclusion.

2. He moots a hypothetical view of the nature of body to confirm his criticism of the proof.

3. He advances an alternative proof of prime matter, which assumes a different strand of hylomorphism.

Avicenna's argument, al-Mas'ūdī submits, is not fit for purpose; for rather than proving that body consists of matter and form, it only goes so far as to illustrate a more general point:

This argument falls short of its intended objective (lā yafi bi-hādhā lgharad). For what is entailed by it is that we have continuity and a recipi-

\footnotetext{
48 Ibn Ghaylān, Hudūth al-'ālam, 123.

49 Al-Rāzī, Jawābāt, 19.

5o Shukūk, 197. See p. 159 above.
} 
ent thereof, and that the two are different. This, however, is an indubitable fact.

The problem, of course, is that by proving the presence of continuity and a receptacle thereof, Avicenna, according to his critic, still has to show that the continuity in question is a substantial form and not merely an accident.

Al-Mas'ūdì goes on to make a case for the possibility that Avicenna fails to address, namely that the continuity-and-recipient dichotomy evinced in the argument is merely the dichotomy of accidental magnitude and body. $\mathrm{He}$ writes:

One may argue (li-qãal an yaqūla) that the continuity that passes away at the occurrence of discontinuity, and that the like of which then comes to be when discontinuity comes to an end [i.e. when continuity is restored], is an accident in the category of continuous quantity ('arad min bāb al-kammiyya al-muttașila), and that the subject (mawdiūc) that receives it is none other than body.

A single lump of wax, for instance, has magnitude, three-dimensionality and continuity. It may then become subject to discontinuity and fragmentation, if it is divided into portions, split into parts, and made multiple separate pieces. What passes away, and is lost, as a result of this division and fragmentation is only the unity (wahda) that was in [the original lump of wax], the magnitude that it had, and the continuity that existed in act within it between its postulated parts. It is manifestly evident that all of these are accidents that supervene upon body and pass away, while the reality ( haqiq a) of body is altered neither by its supervention nor passing away. For every part that becomes separate from the lump of wax is no less a lump of wax than the one from which it was separated, and the two differ in nothing but some accident or other, such as magnitude or the like.

Every body has a magnitude and [accidental] continuity. This magnitude and continuity may pass away, and the like of which may then come to be anew, but the corporeity that the body will have after [either of these changes] will remain the same as it was beforehand. For the form by which [corporeity] subsists remains the same in both cases [i.e. in both types of change.$^{51}$ 
So, when a body is divided, there will be no loss of continuity, in the sense of formal corporeity, since the resultant parts will be no less corporeal than the original body. The passing away and coming-to-be of quantitative continuity only attest the inherence of accidents of magnitude in body, but not the subsistence of corporeity, as a substantial form, in matter.

Al-Mas'ūdì's objection starts with the contention that Avicenna's argument falls short of its purported goal, since it only evinces a dichotomy of continuity and recipient in body, which is an equivocal conclusion, as the dichotomy evidenced can be that of (A) substantial form and matter, or (B) accidental form and body. He proposes an alternative reading of the division hypothesised in body, yielding B. So al-Mas'ūdī concludes this particular objection by asserting that Avicenna needs a further argument to establish A. Al-Mas'ūdī himself affirms B not merely for the sake of argument, but as a genuine commitment.

The second part of al-Mas'ūil's criticism is a follow-up challenge, which echoes the characteristic style of al-Ghazâlì's Tahäfut. He begins with the formulaic rhetorical question, 'How do you counter one who asserts ...' (bi-ma tunkirūna 'alā man yaqūlu bi-), which occurs numerous times in the Tahäfut, where it generally introduces views that are contrary to the philosophers' doctrines, and that they do not, or arguably cannot, disprove. The views submitted may be actual commitments of the questioner, or may be postulated purely for the sake of argument, in order to undermine the respondent's position. ${ }^{52}$ The challenge mooted by al-Mas'ū ūi is of the latter type.

He postulates that body is a simple, non-composite and self-subsisting substance, and that the reality of any given body is its species form (șüra naw ìyya). For instance, the reality of a lump of wax is simply the form of wax (șürat al-shamiyya), which is not combined with anything. Any particular lump of wax, however, will invariably be characterised by accidents of magnitude; and if any of these accidents undergo change-for instance, if the body is divided or reshaped - the reality and essence of the lump of wax will not be affected. The fact that such a hypothetical state of affairs involves no absurdities, but seems entirely plausible, confirms, in al-Mas'üdì's view, that Avicenna's argument from discontinuity fails to entail that body is not a simple substance, but a complex of matter and form. He concludes:

Therefore, a demonstration is still needed (lā budda min al-burhān) to prove that this form is not self-subsistent, but rather subsists in a recipient, which is its matter and substrate. What you [Avicenna] have ad- 
duced - namely, that there is something that receives continuity, and is other than the continuity received - does not entail this conclusion. For the recipient that you have evinced is the reality of body, and the continuity it receives is an accident, the subject of which is body. ${ }^{53}$

To recap, Avicenna fails to prove that body consists of matter and form; and a proof 'is still needed'. In the remainder of the section, al-Mas'üdī himself will provide this proof. What is at stake, however, is not only the proof, but Avicenna's theory of matter and corporeal form.

The alternative proof is provided in the third and final part of the section. Al-Rāzī observes that here again al-Mas'ūdī is reliant on Abū l-Barakāt: 'After the esteemed objector [al-Mas'üdī] finished setting out the objection given by al-Shaykh Abū l-Barakāt to establish that [Avicenna's] proof for the existence of matter is specious, he endorsed his theory of matter. ${ }^{54}$ Al-Mas'ū ūi introduces his alternative proof of prime matter with the phrase, 'As to what we have arrived at through investigation (ammä lladhī intahà ilay-hi l-bahth) to prove matter ..., signalling the end of the dialectical discussion in the section. ${ }^{55}$ Some bodies, he argues, undergo alteration with respect to species, such that one essence passes away and a different essence comes to be. Such a qualitative alteration, however, does not change the body in its entirety. For something will remain unchanged before and after the alteration, neither passing away nor coming to be. For example, an egg, when it hatches, becomes altered into a bird, and sperm is altered into an animal. Wheat, when prepared for consumption and then ingested and digested, is altered, respectively, into flour, dough, bread, chyle, blood and finally flesh and bones. In each of these cases, something in the body is altered, but the body does not pass away completely. So there must be something in the body that remains constant, and receives the different alternating species that come to be and pass away. Al-Mas'ūdī concludes:

The thing that receives these things and serves as their substrate is what we call 'hyle' and 'matter'. It is not a thing we can perceive with any of our senses, but it is knowable by the testimony of reason. As to these alternating things, we call them 'forms' and 'accidents'. You have already come to know the difference between form and accident: with [the alteration of] some of these things the species is altered, and with [the alteration of oth-

\footnotetext{
53 Shukūk, 198-199.

54 Al-Rāzì, Jawābāt, 19.

55 Shukūk, 199.
} 
ers] it is not altered; that [whose alteration] alters the species is a form, and that [whose alteration] does not alter [the species] is an accident. ${ }^{56}$

So body consists of a complex of matter and species form. Corporeity, accordingly, belongs to matter, and is not invested to it by a distinct form. Although Abū l-Barakāt is not mentioned in the section, he is clearly the direct source both of this strand of hylomorphism, and of the supporting proof put forth by al-Mas'ūdī.

$5^{6} \quad$ Shukūk, 199-200. 